\title{
Rastislav Metruk
}

Ph.D., Senior lecturer Faculty of Humanities, Department of English Language and Literature University of Žilina, Žilina, Slovakia

rastislav.metruk@gmail.com

\section{USING ENGLISH MOVIES AND TV PROGRAMS FOR DEVELOPING LISTENING SKILLS OF EFL LEARNERS}

\begin{abstract}
The skill of listening has always been regarded as one of the primary skills in foreign language teaching. The article attempts to investigate the effects of employing ICT, namely extensive viewing of movies and TV programs, on listening skills of EFL (English as a foreign language) learners. A total of 18 students of Teaching English Language and Literature study program were targeted for this preliminary study. Based on the data acquired by a questionnaire, they were divided into three groups: those who watch movies and TV programs in the original in English on a daily basis 1 hour a day, 2 hours a day, and 3 and more hours a day. Afterwards, all the participants took a listening test, and the obtained data were subsequently analyzed using the Friedman ANOVA non-parametric statistical test and a post-hoc test. The preliminary results illustrate that despite the fact that some differences in the mean scores were observed, no statistically significant difference was detected in the listening test scores between the three groups $(\mathrm{p}=0.31)$. In a similar way, the post-hoc test yielded the same results $(\mathrm{p}=0.68 ; \mathrm{p}=0.22 ; \mathrm{p}=$ 0.22 ). Thus, the amount of daily exposure to watching English movies and TV programs in the original did not seem to occupy a substantial role in relation to listening skills of EFL learners. It is vital that further research, on a larger sample of respondents, be conducted, also due to the fact that the exploration of this field of English language teaching and learning is still in its infancy. Extensive listening (extensive viewing) represents a useful and popular way of improving listening skills, which requires attention of teachers and students, and this preliminary study explores whether higher exposure to viewing movies and TV programs results in better listening skills of EFL learners.
\end{abstract}

Keywords: listening skills; extensive listening; extensive viewing; ICT; English movies; English TV programs; EFL learner.

\section{INTRODUCTION}

The problem statement. The four language skills (listening, reading, writing and speaking) represent principal components of the command of a foreign language, but it is through the receptive skills, namely listening and reading that EFL learners are exposed to meaningful language so that they can develop their language abilities.

Thus, the significance of listening skills in EFL teaching and learning is undeniable. Listening comprehension is an important part of learning a language, which needs to be developed ([1], [2], [3], [4]. Brownell [5] maintains that listening may be the single most important skill promoting personal and professional development since it influences the effectiveness of individuals, both at school and in the workplace Similarly, Korkmaz and Güneyli [6] also claim that the skill of listening is more important than other language skills (reading, writing, speaking) as it is the first acquired skill.

However, listening has long been neglected in EFL teaching and learning [7], [8], [9], [10], [11] in spite of its immense importance. It seems that listening still continues to be one of the least developed abilities of foreign language students. "Helping students develop listening proficiency has always been a particularly difficult aspect of foreign language teaching, not least because listening involves a number of complex, interrelated cognitive processes which must occur simultaneously within fractions of a second for a message to be interpreted correctly" [12, p. 299]. It should be, therefore, remembered that paying insufficient attention to this skill in foreign language teaching and learning may seriously 
impede the development of overall proficiency of EFL learners [13]. Kim [14] also asserts that the complex nature of listening skills and problems language learners encounter during listening to foreign language deserves serious thought and investigation.

"It is a fact that technology is in every part of our lives" [15, p. 2587]. Thus, technologies affect most aspects of our daily work as they have produced changes in every sphere of society [16], [17], including education [18], [19]. Moreover, they help EFL learners enhance their language abilities [20], [21]. "There are many benefits to using ICTs (information and communication technologies) as an educational tool" [22, p. 176]. One of the groups ICT applications can be categorized into is the so-called learning resources, which include educational software, online resources, and video resources [23]. Therefore, extensive listening or extensive viewing represents one of the ways how foreign language learners can develop their language skills. Chang [24] explains that extensive listening includes listening to a huge amount of aural input, either live or through radio, TV, the Internet, audio books, etc. "Extensive listening does not require listening for specific information, listening for the exact words of a phrase or expression, or listening for details" [25, p. 29]. Siyanova-Chanturia and Webb [26] maintain that a recently emerged concept in the literature, which refers to watching TV, movies, and videos for the purposes of L2 (second language) learning, is called extensive viewing. In connection with this, Renandya and Jacobs [27, p. 101] state that "[b]ecause of the rich visual elements that provide contextual supports, L2 students find it easier to comprehend videos than audio recordings". Thus, extensive viewing can be deemed popular with foreign language learners.

Despite the fact that advocates of extensive listening claim that this type of listening is likely to improve performance and attitudes of learners [28], and that extensive listening is of obvious importance [29], it should be noted that research into the effects of extensive listening is still in its infancy [27]. In connection with this, Chang and Millett [30, p. 31] state that "[d]ue to the fact that EL is a comparatively new idea, its theoretical framework is underdeveloped; there has been little hard evidence supporting the effect of EL on improving L2 listening competence". Therefore, further research on extensive listening (extensive viewing) ought to be carried out so as to throw new light on this field of EFL teaching and learning.

This study attempts to fill in the gap by focusing on practicing listening skills of EFL learners by watching movies and TV programs in the original in English. The article examines the effects of extensive viewing on EFL learners' listening skills. Its principal objective is to investigate the influence of three types of daily exposure ( 1 hour a day, 2 hours a day, 3 and more hours a day) to watching movies and TV programs in the original (in English) on listening skills of Slovak university EFL students. Another goal is to compare the three groups of participants with each other by means of statistical tests.

\section{THE THEORETICAL BACKGROUNDS}

Research has supported the notion that exposing learners to authentic materials through video aids learning of a language, listening skills in particular [31]. Arising out of the analysis of several studies, Kim [32] also suggests that videos can be beneficial for the improvement of listening skills of L2 learners. In her own study, Kim's [31] research findings support the notion that videos are a more useful and effective tool for the development of listening in comparison to the lecture-based instruction.

According to Safranj [33], the use of movies is an effective way of improving listening abilities of foreign language learners, also resulting in getting better insight into English culture. A large-scale survey conducted by Canning-Wilson [34] illustrates that students expressed their preference for learning language through the use of videos. "One of the results 
of her survey shows that learners prefer action/entertainment films to language films or documentaries in the classroom" [35]. Furthermore, she claims that in spite of the fact that these movies appear to hold student interest, it might be inferred that student comprehension of videos can be due to the visual clues instead of auditory components.

In her study, Khan [36] emphasized the implications of using movies so as to enhance language proficiency of non-native speakers, indicating that higher exposure to watching movies may lead to considerable increase in L2 acquisition in non-native English language learning environments. According to Mekheimer [37], authentic videos represent a valuable approach in regard to whole language learning.

Kacetl and Fiserova [38] maintain that in this day and age, it is not difficult to find suitable videos on the Internet, and that teachers of foreign languages use them frequently. They mention some of the useful websites as follows: YouTube, Yahoo!, Video, TeacherTube, Hulu, Netflix, OneWorldTV, Google Video, MSN Soapbox, NextVista, Discovery Education, or Deutsche Welle. Therefore, L2 learners can choose from a broad range of sources when they want to watch a movie or a TV program. In relation to YouTube, which also contains numerous movies and TV programs, Watkins and Wilkins [39] indicate that there are two primary benefits of using YouTube in the classroom, namely exposure to authentic English and the promotion of a more autonomous and student-centered learning style.

However, when it comes to using YouTube in relation to extensive viewing, according to the study conducted by Kelsen [40], 53.3\% of participants regarded YouTube less then neutral in motivating them to learn English outside their classes. "This may reflect that in the absence of a teacher and structured activities, many students are unaware of how to, or perhaps unwilling to, use YouTube for anything other than entertainment" [40, p. 10]. Similarly, the study of Silviyanti [41] also suggests that students find YouTube more beneficial to their English and were more motivated when used in class in comparison to using YouTube outside of the class.

It is also television which can be used for the purposes of extensive viewing. According to Rodgers [42], watching L2 television improves listening comprehension. Webb [43, p. 159] also recognizes the importance of television, which is a good example of a valuable source of authentic materials, by claiming that " $[\mathrm{t}]$ he greatest value of television for language learning might be its potential to provide large amounts of L2 spoken input, which can contribute to the development of vocabulary knowledge and listening comprehension, as well as other aspects of L2 learning". Webb and Nation [44] maintain that although people have a tendency to spend more time watching TV than reading in their native language, it may seem odd that relatively little discussion has been generated with regard to the value of extensive viewing when it comes to language learning. One of the reasons for this is that watching TV is more strongly linked with entertainment rather than education. However, the fact that a lot of people watch TV for enjoyment ought to be regarded as a major advantage for language learning. "If learners can also watch L2 television programs for enjoyment, then they are more likely to use them as a source of meaning-focused input" [44].

Extensive listening and viewing indeed has its place in foreign language learning. However, research in this field is scarce, hence the need for further investigation into the effects of practicing the skill of listening outside the classroom. 


\section{RESEARCH METHODOLOGY}

\subsection{Research design}

The article explores the effects of extensive viewing on listening skills of EFL learners. Its primary objective is to analyze the influence of three types of daily exposure ( 1 hour a day, 2 hours a day, 3 and more hours a day) to watching movies and TV programs in the original (in English) on listening skills of Slovak university EFL students. Another goal is to compare the three groups of participants with each other by means of statistical tests.

The research participants were divided into three groups according to their long-term viewing habits (watching movies and TV programs in the original in English 1 hour a day, watching movies and TV programs in the original in English 2 hours a day, and watching movies and TV programs in the original in English 3 and more hours a day). Afterwards, the participants took a listening test. Finally, the data were obtained, statistically compared by means of the Friedman ANOVA and a post-hoc test, results were interpreted, and conclusions were reached.

\subsection{Participants}

The target population were the third year B.A. students and the first year M.A. students of the study program Teaching of English Language and Literature at a university in Slovakia. The total sample $(\mathrm{n}=18)$ was formed by 10 females and 8 males. All the students were approximately at the CEFR B2+ level. They were 22.4 years of age on average, all of them holding Slovak nationality, living in Slovakia. The participants had been learning English for more than 10 years. All of them claimed that they would watch English movies and TV programs on a daily basis.

\subsection{Data collection and procedure}

The respondents were asked to complete a short questionnaire in order to acquire data regarding the daily time they would spend on watching movies and TV programs. Afterwards, they were divided into three groups as follows:

1. Students who watch movies and TV programs in the original in English on a daily basis one hour a day;

2. Students who watch movies and TV programs in the original in English on a daily basis two hours a day;

3. Students who watch movies and TV programs in the original in English on a daily basis three and more hours a day.

Next, all the participants in every group took a standardized listening test so as to find out how many points they have scored. The students were able to achieve the maximum of 28 points (18 fill-in-the-blank and multiple choice items). The obtained data were subsequently analyzed and compared by means of the analytics software Statistica 10.0 so as to reveal whether the differences between the three groups are statistically significant or not.

\section{THE RESULTS AND DISCUSSION}

The listening test scores are displayed in Table 1 and Figure 1. The highest average can be observed with the students who watch English movies and TV programs 3 and more hours a day (23.3), followed by those who view movies and TV shows 1 hour a day (19.8), and the participants that are exposed to watching movies and TV programs 2 hours a day (19). 
Table 1

Listening test scores

\begin{tabular}{|c|c|c|}
\hline \multicolumn{3}{|c|}{ Listening test scores } \\
\hline $\begin{array}{c}\text { Exposure 1 hour a day } \\
\text { Participants 1 - 6 }\end{array}$ & $\begin{array}{c}\text { Exposure 2 hours a day } \\
\text { Participants } 7-12\end{array}$ & $\begin{array}{c}\text { Exposure 3+ hours a day } \\
\text { Participants 13-18 }\end{array}$ \\
\hline 16 & 19 & 23 \\
\hline 25 & 18 & 27 \\
\hline 7 & 14 & 26 \\
\hline 25 & 18 & 22 \\
\hline 26 & 23 & 16 \\
\hline 20 & 22 & 26 \\
\hline Mean: 19.8 & Mean: 19.0 & Mean: 23.3 \\
\hline
\end{tabular}

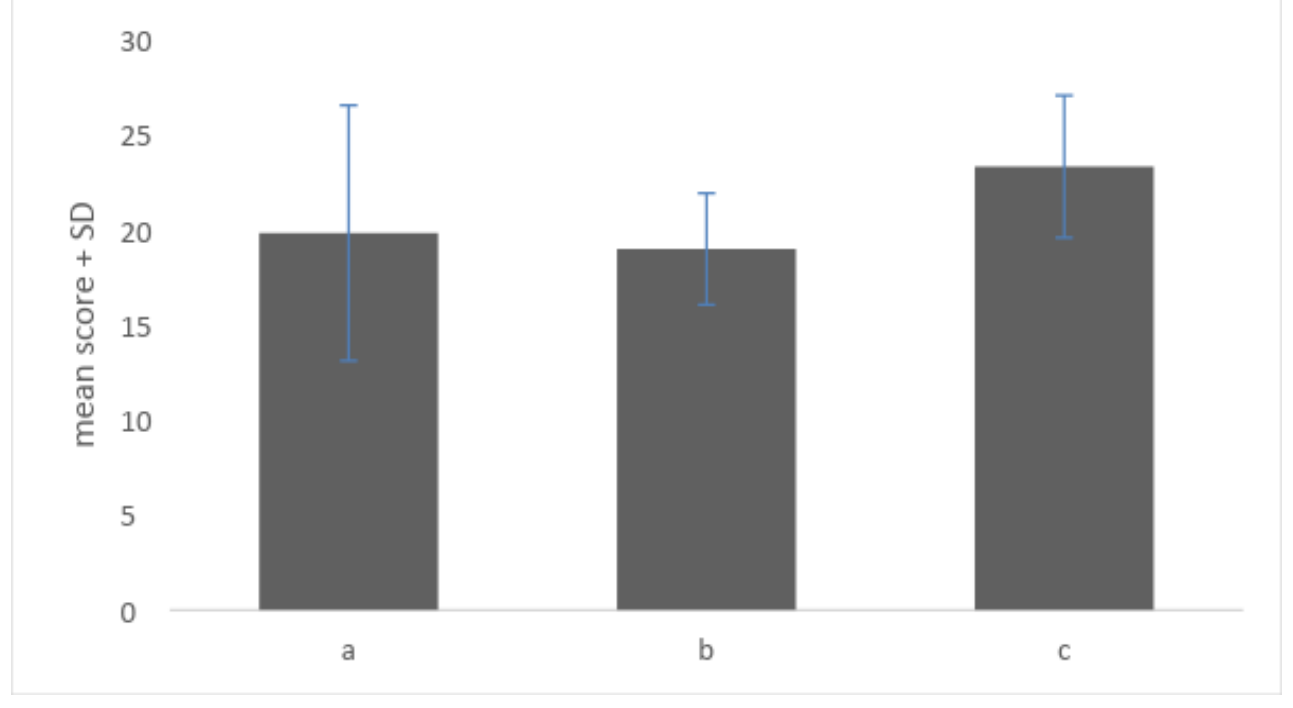

Figure 1. Listening test scores and standard deviations

The obtained data illustrate that the students who watch English movies and TV programs 3 and more hours a day achieved the highest scores (23.3). Moreover, the participants who were exposed to watching English movies and TV programs 1 hour a day obtained a slightly better mean listening test score (19.8) in comparison to those who watch movies and TV programs 2 hours a day (19). The difference between the test scores of the participants who watch English movies and TV programs 1 hour a day and 2 hours a day, however, seems to be of minor importance.

For the purposes of examining if the differences between the average test scores are of statistical significance, the Friedman ANOVA non-parametric statistical test and a post-hoc test were employed. The main findings demonstrate that no statistically significant difference was detected between the three groups of students in the listening test scores at the significance level of $0.05(\mathrm{~F}=2.33 ; \mathrm{p}=0.31)$.

The post-hoc test (Table 2), which was used for comparing the three groups with each other ( 1 hour a day vs 2 hours a day, 1 hour a day vs $3+$ hours a day, 2 hours a day vs $3+$ hours a day), also revealed that no statistically significant differences were observed. Thus, the amount of exposure did not seem to occupy a powerful role as far as the participants' listening skills are concerned. 
Table 2

Post-hoc test for the listening test scores

\begin{tabular}{|c|c|c|}
\hline Treatments pair & p-value & Difference \\
\hline 1 hour vs 2 hours & 0.68 & not significant \\
\hline 1 hour vs 3+ hours & 0.68 & not significant \\
\hline 2 hours vs 3+ hours & 0.22 & not significant \\
\hline
\end{tabular}

\section{CONCLUSIONS AND PROSPECTS FOR FURTHER RESEARCH}

Listening is a skill of crucial importance, which deserves serious attention of both EFL teachers and learners, and one of the ways how foreign language learners can enhance this skill is by practicing extensive listening. This study focused on the development of listening skills by watching English movies and TV programs in the original in English. Examining whether higher daily exposure to watching English movies and TV programs results in higher listening test scores was in the foreground of this study.

The statistical comparison has revealed that despite some differences between the average listening scores $(1$ hour a day $=19.8 ; 2$ hours a day $=19 ; 3+$ hours a day $=23.3$ ), statistically significant differences were not detected. At the same significance level of 0.05 , the post-hoc test, which was used for comparing the three groups with each other, generated the same results ( 1 hour a day vs 2 hours a day: $\mathrm{p}=0.68$; 1 hour a day vs $3+$ hours a day: $\mathrm{p}=$ $0.68 ; 2$ hours a day vs $3+$ hours a day: $p=0.22$ ). Therefore, these preliminary research results do not seem to support the assumption that higher daily exposure to watching movies and TV programs in the original (in English) would necessarily lead to better listening skills of EFL learners.

One of the limitations of this study is a relatively low number of participants, which means that the generalizability of the findings is decreased. This paper, however, is regarded as a preliminary study, and further research, conducted on a larger sample of respondents, needs to be performed, also due to the fact that the exploration of this field of English language teaching and learning is still in its infancy. Moreover, employing other research methods such as interview or observation as well as examining listening skills at other CEFR levels than B2+ would definitely prove useful.

Further research might concentrate also on web or cloud services in terms of developing language skills of EFL learners, or exploring the advantages of employing ICTs such as the Internet or various online resources for the purposes of enhancing listening skills in comparison to watching, for example, TV and DVD players only. It is obvious that the popularity and the integration of ICTs in every sphere of human activity will continue to grow, hence the need for further exploration in this area, also in the context of EFL learning.

Extensive listening (extensive viewing) is undoubtedly a matter of considerable significance, and can be regarded as an interesting and useful way of practicing listening skills. Technological advancements and the Internet offer ample opportunity for watching authentic English movies, TV programs, and videos, and EFL learners should not be afraid of using them to their advantage. Finally, it ought to be noted that teachers worldwide have to encourage their learners in practicing extensive listening (extensive viewing) as much as possible since this way of developing one's language abilities definitely has its place in foreign language learning. 


\section{REFERENCES (TRANSLATED AND TRANSLITERATED)}

[1] Gilakjani, A., and Sabouri, N. (2016). "Learners' Listening Comprehension Difficulties in English Language Learning: A Literature Review”, English Language Teaching, Vol. 9 No 6, pp. 123-133. http://dx.doi.org/10.5539/elt.v9n6p123

[2] Gilakjani, A., and Sabouri, N. (2016). "The Significance of Listening Comprehension in English Language Teaching", Theory and Practice in Language Studies, Vol. 6 No. 8, pp. 1670-1677. http://dx.doi.org/10.17507/tpls.0608.22

[3] Mohajer, S., and Pourgharib, B. (2014). "The Effect of Captioned Videos on Advanced EFL Learners' Listening Proficiency in Iran”, International Journal of Basic Sciences \& Applied Research, Vol. 3 No. 12, pp. 951-957. [online]. Available: http://isicenter.org/fulltext/paper-352.pdf

[4] Pokrivčáková, S. (2010). Modern Teacher of English. ASPA, Nitra, Slovakia.

[5] Brownell, J. (2016). Listening Attitudes, Principles, and Skills. Routledge, New York, USA.

[6] Korkmaz, S., and Güneyli, A. (2017). "Impact of Technology-Assisted Context-Based Teaching on the Listening Skills of Teacher Candidates", EURASIA Journal of Mathematics Science and Technology Education, Vol. 13 No. 8, pp. 4669-4677. doi:10.12973/eurasia.2017.00957a

[7] Bakhtiarvand, M., and Adinevand, S. (2011). "Is Listening Comprehension Influenced by the Cultural Knowledge of the Learners? A Case Study of Iranian EFL Pre-intermediate Learners", RELC Journal, Vol. 42 No. 2, pp. 111-124. https://doi.org/10.1177/0033688211401257

[8] Gilakjani, A., and Ahmadi, M. (2011). “A Study of Factors Affecting EFL Learners' English Listening Comprehension and the Strategies for Improvement", Journal of Language Teaching and Research, Vol. 2 No. 5, pp. 977-988. https://doi.org/10.4304/jltr.2.5.977-988

[9] Kavaliauskienė, G. (2008). "Podcasting: a Tool for Improving Listening Skills", Teaching English with Technology, Vol. 8 No. 4.

[10] Kazemi, A., and Kiamarsi, S. (2017). “An Investigation into Listening Comprehension Strategies and the Relationship between Listening Comprehension Strategies and Overall Proficiency Level of Intermediate and Advanced Learners", Journal of Language Teaching and Research, Vol. 8 No. 1, pp. 149-156. https://doi.org/10.17507/jltr.0801.18

[11] Yildiz, N., Parjanadze, N., and Albay, M. (2015). "The Effect of Question Position on Listening Comprehension: A Case Study”, International Journal of Social Sciences \& Educational Studies, Vol. 2 No. 1, pp. 4-9.

[12] Holden, W. (2008). "Extensive Listening: A New Approach to an Old Problem", Journal of the Faculty of Humanities, University of Toyama, Vol. 49, pp. 299-312.

[13] Metruk, R. (2018). "The Effects of Watching Authentic English Videos with and without Subtitles on Listening and Reading Skills of EFL Learners", EURASIA Journal of Mathematics, Science and Technology Education, Vol. 14 No. 6, pp. 2545-2553. https://doi.org/10.29333/ejmste/90088

[14] Kim, H. (2015). "Using Authentic Videos to Improve EFL Students' Listening Comprehension", International Journal of Contents, Vol. 11 No. 4, pp. 15-24. doi:10.5392/IJoC.2015.11.4.015

[15] Altinc1, R., and Mohammadzadeh, B. (2018). "Research into the Effects of an ICALL Program on Teaching Word Classes to Learners of English", EURASIA Journal of Mathematics Science and Technology Education, Vol. 22 No 6, pp. 2587-2598. https://doi.org/10.29333/ejmste/90093

[16] Vaskivska, H., Kosianchuk, S., \& Skyba, H. (2017). Didactic Possibilities of Information and Communication Technologies in the Process of Development of Educational Environment in Upper Secondary School. Information Technologies and Learning Tools, 60(4), 17-27. [online]. Available: https://journal.iitta.gov.ua/index.php/itlt/article/view/1790/1228

[17] Moskalenko, O., \& Didenko, O. (2018). A Computer Tool for Training Pilots' Listening Skills in Aviation English. Information Technologies and Learning Tools, 67(5), 187-198.

[18] Doulík, P., Škoda, J., and Šimonová, I. (2017). "Learning Styles in the e-Learning Environment: The Approaches and Research on Longitudinal Changes", International Journal of Distance Education Technologies, Vol. 15 No 2, pp. 45-61. https://doi.org/10.4018/IJDET.2017040104

[19] Pokrivčáková, S. (2017). "Evaluating CD ROMs for Pre-Primary English Courses in the Czech Republic and Slovakia”, International Journal on Language, Literature and Culture in Education, Vol. 4 No. 2, pp. 3-25.

[20] Lu, J., and Price, J. (2018). “Chinese Students' ICT Readiness for a Blended Teaching and Learning Environment”, Eurasia Journal of Mathematics, Science and Technology Education, Vol. 14 No. 7, pp. 2907-2914. https://doi.org/10.29333/ejmste/90991

[21] Peterson, E. (2010). “Internet-based Resources for Developing Listening”, Studies in SelfAccess Learning Journal, Vol. 1 No. 2, pp. 139-154. 
[22] Baş, G., Kubiatko, M., and Sünbül, A. (2016). "Teacher's Perceptions towards ICTs in Teaching-learning Process: Scale Validity and Reliability Study", Computers in Human Behavior, Vol 61, pp. 176-185. https://doi.org/10.1016/j.chb.2016.03.022

[23] Collins, B., \& Moonen, J. (2001). Flexible Learning in a Digital World. Experiences and Expectations. London: Kogan Page.

[24] Chang, A. (2017). "What can L2 Teachers do to Assist L2 Learners to Develop Listening Fluency?", Contact, Vol. 43 No. 3, pp. 15-20.

[25] Vo, Y. (2013). "Developing Extensive Listening for EFL Learners using Internet Resources", Hawaii Pacific University TESOL Working Paper Series 11, pp. 29-51.

[26] Siyanova-Chanturia, A., and Webb, S. (2016). "Teaching Vocabulary in the EFL Context", In W. Renandya and H. Widodo (Eds) English Language Teaching Today. Linking Theory and Practice, pp. 227-240. Springer International Publishing, Switzerland.

[27] Renandya, W., and Jacobs, G. (2016). "Extensive Reading and Listening in the L2 Classroom", In W. Renandya and H. Widodo (Eds.), English Language Teaching Today. Linking Theory and Practice, pp. 97-110. Springer International Publishing, Cham, Switzerland.

[28] Graham, S., and Santos, D. (2015). Strategies for Second Language Listening. Current Scenarios and Improved Pedagogy. Palgrave Macmillan, Basingstoke, UK.

[29] Onoda, S. (2012). "The effect of QuickListens and Extensive Listening on EFL listening skill development", Extensive Reading, World Congress Proceedings, Vol. 1, pp. 176-179.

[30] Chang, A., and Millett, S. (2014). "The Effect of Extensive Listening on Developing L2 Listening Fluency: Some Hard Evidence", ELT Journal, Vol. 68 No. 1, pp. 31-40. https://doi.org/10.1093/elt/cct052

[31] Chung, J. (2002). "The Effects of Using Two Advance Organizers with Video Texts for the Teaching of Listening in English", Foreign Language Annals, Vol. 35 No. 2, pp. 231-241. https://doi.org/10.1111/j.1944-9720.2002.tb03157.x

[32] Kim, H. (2015). "Using Authentic Videos to Improve EFL Students' Listening Comprehension", International Journal of Contents, Vol. 11 No. 4, pp. 15-24. doi:10.5392/IJoC.2015.11.4.015

[33] Safranj, J. (2015). “Advancing Listening Comprehension through Movies", Procedia - Social and Behavioral Sciences, Vol. 191, pp. 169-173. https://doi.org/10.1016/j.sbspro.2015.04.513

[34] Canning-Wilson, C. (2000). "Role of Video in the F/SL Classroom", In S. Riley, S Troudi and C. Coombe. (Eds.) Teaching, Learning and Technology, TESOL Arabia 1999 Conference Proceedings, pp. 69-76.

[35] Canning-Wilson, C. (2000). "Practical Aspects of Using Video in the Foreign Language Classroom", The Internet TESL Journal, Vol. 6 No. 11.

[36] Khan, A. (2015). "Using Films in the ESL Classroom to Improve Communication Skills of Non-Native Learners", ELT Voices - International Journal for Teachers of English, Vol. 5 No. 4, pp. 46-52.

[37] Mekheimer, M. (2011). "The Impact of Using Videos on Whole Language Learning in EFL Context", Arab World English Journal, Vol. 2 No. 2, pp. 5-39. [online]. Available: http://awej.org/images/AllIssues/Volume2/Volume2Number2April2011/1.pdf

[38] Kacetl, J., and Fiserova, M. (2016). "Online Video Clips in Foreign Language Teaching”, In M. Bilgin, H. Danis, E. Demir and U. Can Business Challengers in the Changing Economic Landscape, Vol. 2, pp. 355-365. Springer, Cham, Switzerland.

[39] Watkins, J., \& Wilkins, M. (2011). "Using YouTube in the EFL Classroom”, Language Education in Asia, Vol. 2 No. 1, pp. 113-119.

[40] Kelsen, B. (2009). "Teaching EFL to the iGeneration: A Survey of Using YouTube as Supplementary Material with College EFL Students in Taiwan”, CALL-EJ Online, Vol. 10 No. 2, pp. 1-18.

[41] Silviyanti, T. (2014). "Looking info EFL Students' Perceptions in Listening by Using English Movie Videos on YouTube", Studies in English language and Education, Vol. 1 No. 1, pp. 42-58.

[42] Rodgers, M. (2013). English language learning through viewing television: An investigation of comprehension, incidental vocabulary acquisition, lexical coverage, attitudes, and captions (Unpublished PhD. thesis). Wellington: New Zealand.

[43] Webb, S. (2015). “Extensive Viewing: Language Learning through Watching Television", In D. Nunan and J. Richards (Eds.) Language Learning Beyond the Classroom, pp. 159-168. Routledge, New York, USA.

[44] Webb, S., and Nation, P. (2017). How Vocabulary is Learned. Oxford University Press, Oxford, UK. 


\title{
ВИКОРИСТАННЯ АНГЛОМОВНИХ ФІЛЬМІВ І ТЕЛЕВІЗІЙНИХ ПРОГРАМ ДЛЯ РОЗВИТКУ НАВИЧОК СЛУХАННЯ СТУДЕНТІВ ПІД ЧАС ВИВЧЕННЯ АНГЛІЙСЬКОЇ МОВИ ЯК ІНОЗЕМНОЇ
}

\section{Растислав Метрук}

$\mathrm{PhD}$, старший викладач, факультет гуманітарних наук, кафедра англійської мови та літератури Жилінський університет, м. Жиліна, Словаччина rastislav.metruk@gmail.com

\begin{abstract}
Анотація. Уміння слухати завжди вважалося однією 3 основних навичок у навчанні іноземної мови. У статті зроблена спроба вивчити вплив використання IКТ, а саме екстенсивного перегляду фільмів і телепрограм, на навички слухання учнів, які вивчають англійську як іноземну мову. Для попереднього дослідження було обрано 18 студентів, майбутніх учителів англійської мови та літератури. Грунтуючись на даних, отриманих за допомогою опитувальника, вони були розділені на три групи: ті, хто, щодня дивиться фільми і телепрограми англійською мовою 1 годину в день, 2 години на день, 3 і більше годин на день. Після цього всі учасники пройшли тест на прослуховування, і отримані дані були згодом проаналізовані 3 використанням непараметричного статистичного тесту Фрідмана ANOVA і спеціального тесту. Попередні результати показують, що, незважаючи на те, що спостерігалися деякі відмінності в середніх балах, статистично значущих відмінностей у балах тесту на прослуховування між трьома групами не виявлено $(\mathrm{p}=0,31)$. Аналогічним чином пост-спеціальний тест дав ті ж результати $(\mathrm{p}=0,68 ; \mathrm{p}=0,22 ; \mathrm{p}=0,22)$. Отже, кількість щоденного прослуховування під час перегляду англійських фільмів i телепрограм в оригіналі не зіграв істотної ролі в поліпшенні навичок слухання учнів EFL. Вкрай важливо, щоб подальші дослідження, що проводяться на більш широкій вибірці респондентів, проводилися також у зв'язку 3 тим фактом, що вивчення цієї галузі викладання і вивчення англійської мови все ще перебуває в зародковому стані. Інтенсивне прослуховування (розширений перегляд) є корисним і популярним способом поліпшення навичок прослуховування, який вимагає уваги вчителів і студентів, і в цьому попередньому дослідженні розглядається питання, чи приводить екстенсивне слухання під час перегляду фільмів і телепрограм до поліпшення навичок слухання учнів EFL.
\end{abstract}

Ключові слова: вміння слухати; екстенсивне слухання; екстенсивний перегляд; IКТ; англійські фільми; телевізійні програми англійською мовою; учень EFL.

\section{ИСПОЛЬЗОВАНИЕ АНГЛОЯЗЫЧНЫХ ФИЛЬМОВ И ТЕЛЕВИЗИОННЫХ ПРОГРАММ ДЛЯ РАЗВИТИЯ НАВЫКОВ СЛУШАНИЯ СТУДЕНТОВ ПРИ ИЗУЧЕНИИ АНГЛИЙСКОГО ЯЗЫКА КАК ИНОСТРАННОГО}

\section{Растислав Метрук}

$\mathrm{PhD}$, старший преподаватель, гуманитарный факультет, кафедра английского языка и литературы Жилинский университет, г. Жилина, Словакия rastislav.metruk@gmail.com

\footnotetext{
Аннотация. Умение слушать всегда считалось одним из основных навыков в обучении иностранному языку. В статье предпринята попытка изучить влияние использования ИКТ, а именно экстенсивного просмотра фильмов и телепрограмм, на навыки слушания учащихся, изучающих английский как иностранный язык. Для предварительного исследования было выбрано 18 студентов, будущих учителей английского языка и литературы. Основываясь на данных, полученных с помощью вопросника, они были разделены на три группы: те, кто ежедневно смотрит фильмы и телепрограммы на английском языке 1 час в день, 2 часа в день, 3 и более часов в день. После этого все участники прошли тест на прослушивание, и полученные данные были впоследствии проанализированы с использованием непараметрического статистического теста Фридмана ANOVA и специального теста. Предварительные результаты показывают, что, несмотря на то, что наблюдались некоторые различия в средних баллах, статистически значимых различий в баллах теста на прослушивание между тремя группами не обнаружено $(\mathrm{p}=0,31)$. Аналогичным образом,
} 
пост-специальный тест дал те же результаты ( $\mathrm{p}=0,68 ; \mathrm{p}=0,22 ; \mathrm{p}=0,22)$. Таким образом, количество ежедневного прослушивания во время просмотра английских фильмов и телепрограмм в оригинале не сыграло существенной роли в улучшении навыков слушания учащихся EFL. Крайне важно, чтобы дальнейшие исследования, проводимые на более широкой выборке респондентов, проводились также в связи с тем фактом, что изучение этой области преподавания и изучения английского языка все еще находится в зачаточном состоянии. Интенсивное прослушивание (расширенный просмотр) представляет собой полезный и популярный способ улучшения навыков прослушивания, который требует внимания учителей и студентов, и в этом предварительном исследовании рассматривается, приводит ли экстенсивное слушание во время просмотра фильмов и телепрограмм к улучшению навыков слушания учащихся EFL.

Ключевые слова: умение слушать; экстенсивное слушание; экстенсивный просмотр; ИКТ; английские фильмы; телевизионные программы на английском языке; ученик EFL. 